\section{'Oconee' Pecan}

T.E. Thompson, E.F. Young, Jr., H.D. Petersen, and L.J. Grauke U.S. Department of Agriculture, Agricultural Research Service, Pecan Genetics and Breeding Station, Route 2, Box 133, Somerville, TX 77879

\section{R.E. Worley}

University of Georgia, Coastal Plains Experiment Station, Tifton, GA 31793

\section{R.D. O'Barr and R.S. Sanderlin}

Pecan Research Station, Louisiana Agricultural Experiment Station, Louisiana State University Agricultural Center, P.O. Box 5519, Shreveport, LA 71135

Additional index words. Carya illinoensis, cultivar, variety
'Oconee' is a new pecan [Calya illinoensis (Wangenh.) K. Koch] cultivar released 29 Dec. 1989 by the Agricultural Research Service (ARS), U.S. Dept. of Agriculture (USDA); the Georgia Agricultural Experiment Station, Athens; the Louisiana Agricultural Experiment Station, Louisiana State Univ., Baton Rouge; and the Texas Agricultural Experiment Station, Texas A\&M other protandrous cultivars, 'Oconee' has the unique characteristics of high yield, large nuts, a high percentage of kernel per nut, and excellent shelling characteristics. Nut maturity is too late to allow culture in extreme northem pecan production areas.

\section{Origin}

'Oconee', tested as selection 56-7-72, is a progeny from a 1956 cross between 'Schley' and 'Barton' made by L.D. Romberg at the W.R. Poage Pecan Field Station, USDAARS, Brownwood, Texas (Fig. 1). The clone was budded to a branch of a bearing tree in

Received for publication 29 Oct. 1990. The cost of publishing this paper was defrayed in part by the payment of page charges. Under postal regulations, this paper therefore must be hereby marked advertisement solely to indicate this fact. Univ., College Station. When compared with
Summer 1957 and was among the first selections of this cross to fruit in 1961. This clone each year (1963-68) produced nuts that were analyzed for nut quality. Based on preliminary performance, extensive testing was started in 1964.

\section{Description}

Yield data taken early during the evaluations indicate that the precocity and yield potential of 'Oconee' are good (Table 1). Grafted trees at Tifton, Ga., started producing the 5th year and have produced a total of $91.4 \mathrm{~kg}$ of nuts per tree through the 10th season (Worley, 1986). Average annual production was $1,3,5,10,13,24,10$, and 25 $\mathrm{kg} /$ tree for the fifth through the 12th seasons, respectively. The nuts are large enough to be sold in-shell or shelled to produce very attractive kernel halves (Fig. 2).

Budbreak of 'Oconee' is similar to that of 'Caddo' and 'Kiowa' and earlier than 'Cheyenne' and a sib clone, 'Shawnee' (Table 2).
Table 1. Performance of 'Oconee' pecan compared with control cultivars at Tifton, Ga., planted in 1979 and measured through 1990. Total nut yield is for 8 years (1983-90).

\begin{tabular}{llccc}
\hline \hline & $\begin{array}{c}\text { Total } \\
\text { nut yield } \\
(\mathrm{kg} / \text { tree })\end{array}$ & $\begin{array}{c}\text { Nut wt } \\
(\mathrm{g})\end{array}$ & $\begin{array}{c}\text { Kernel }^{\mathbf{y}} \\
(\%)\end{array}$ & $\begin{array}{c}\text { Fancy kernels }^{\mathbf{x}} \\
(\%)\end{array}$ \\
\cline { 2 - 5 } Cultivar & $91.4 \mathrm{~b}$ & $9.7 \mathrm{c}$ & $56 \mathrm{~b}$ & $26 \mathrm{ab}$ \\
\hline Oconcc & $70.4 \mathrm{ab}$ & $7.1 \mathrm{a}$ & $55 \mathrm{~b}$ & $33 \mathrm{~b}$ \\
Cheyenne & $84.7 \mathrm{ab}$ & $8.0 \mathrm{~b}$ & $54 \mathrm{~b}$ & $31 \mathrm{ab}$ \\
Shawnee & $63.6 \mathrm{a}$ & $9.1 \mathrm{c}$ & $60 \mathrm{c}$ & $33 \mathrm{~b}$ \\
Forkert & $85.6 \mathrm{ab}$ & $9.7 \mathrm{c}$ & $45 \mathrm{a}$ & $21 \mathrm{a}$ \\
\hline Gloria Grande & &
\end{tabular}

${ }^{x}$ Mean separation within columns by Duncan's multiple range test, $P=0.05$.

y Percentage of kernel per nut.

xSee Worley (1990).

Table 2. Time-related tree characteristics of 'Oconee' pecan compared with control cultivars at Tifton, Ga., planted in 1979 and measured through 1990 (average of 8 years of data).

\begin{tabular}{|c|c|c|c|c|c|c|c|}
\hline \multirow[b]{2}{*}{ Cultivar } & \multirow[b]{2}{*}{ Budbreak } & \multicolumn{2}{|c|}{ Pollen shed } & \multicolumn{2}{|c|}{$\begin{array}{l}\text { Pistil } \\
\text { receptivity }\end{array}$} & \multirow{2}{*}{$\begin{array}{l}\text { Complete } \\
\text { shucksplit }\end{array}$} & \multirow{2}{*}{$\begin{array}{c}\text { Leaf } \\
\text { drop } \\
(50 \%)\end{array}$} \\
\hline & & First & Last & First & Last & & \\
\hline $\begin{array}{l}\text { Oconee } \\
\text { Caddo } \\
\text { Cheyenne } \\
\text { Kiowa } \\
\text { Shawnee }\end{array}$ & $\begin{array}{l}8 \text { Apr. cy } \\
3 \text { Apr. a } \\
9 \text { Apr. cd } \\
4 \text { Apr. b } \\
12 \text { Apr. d }\end{array}$ & $\begin{array}{r}29 \text { Apr. b } \\
25 \text { Apr. a } \\
1 \text { May b } \\
5 \text { May c } \\
8 \text { May d }\end{array}$ & $\begin{array}{r}5 \text { May b } \\
2 \text { May a } \\
7 \text { May b } \\
13 \text { May c } \\
16 \text { May d }\end{array}$ & $\begin{array}{r}7 \text { May b } \\
5 \text { May b } \\
4 \text { May b } \\
30 \text { Apr. a } \\
4 \text { May b }\end{array}$ & $\begin{array}{l}9 \text { May a } \\
8 \text { May a } \\
9 \text { May a } \\
6 \text { May a } \\
9 \text { May a }\end{array}$ & $\begin{array}{l}21 \text { Oct. ab } \\
16 \text { Oct. a } \\
22 \text { Oct. b } \\
30 \text { Oct. c } \\
16 \text { Oct. a }\end{array}$ & $\begin{array}{r}4 \text { Nov. b } \\
16 \text { Nov. a } \\
18 \text { Nov. a } \\
26 \text { Nov. b } \\
30 \text { Nov. } c\end{array}$ \\
\hline
\end{tabular}

zee Wetzstein and Sparks (1983).

yMean separation within columns by Duncan's multiple range test, $P=0.05$. 
Al salg. (F)

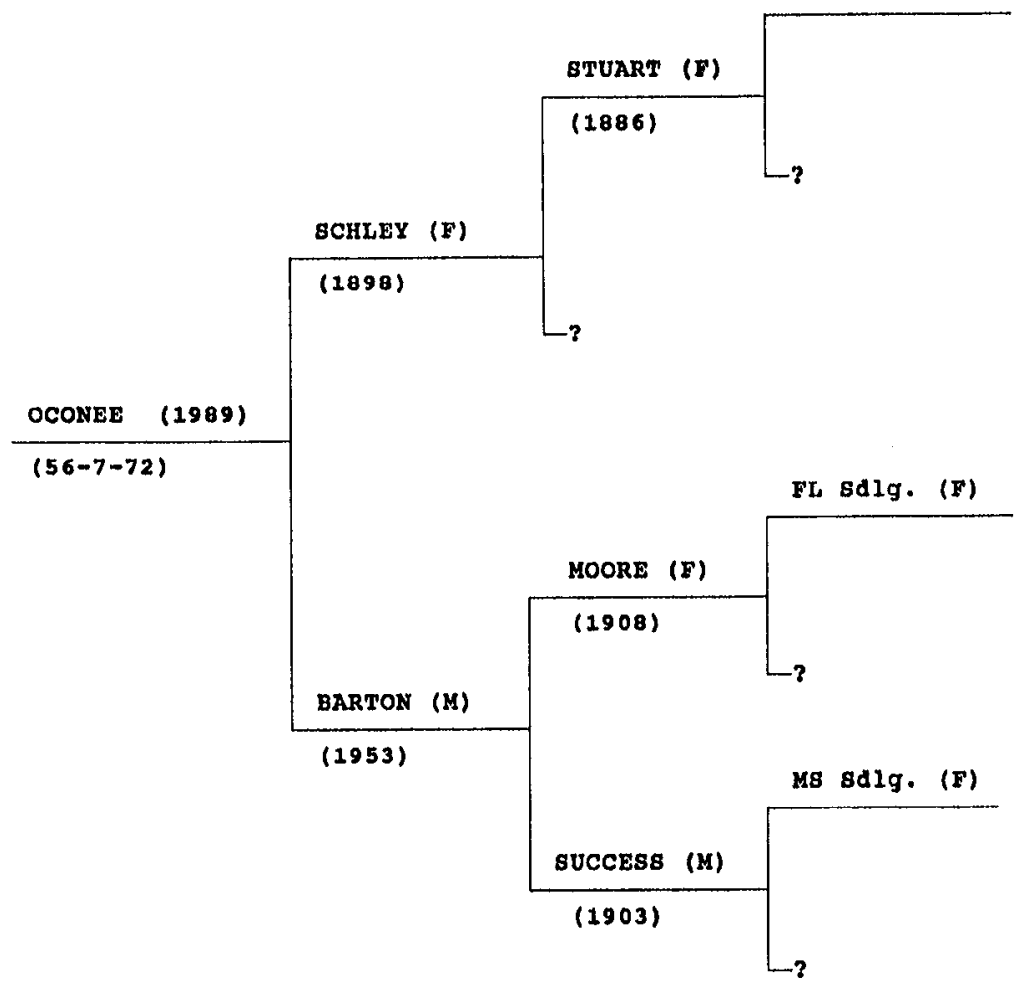

Fig. 1. Pedigree of 'Oconee' pecan, including the year each cultivar was named. $\mathrm{F}=$ female parent and $\mathrm{M}=$ male parent.

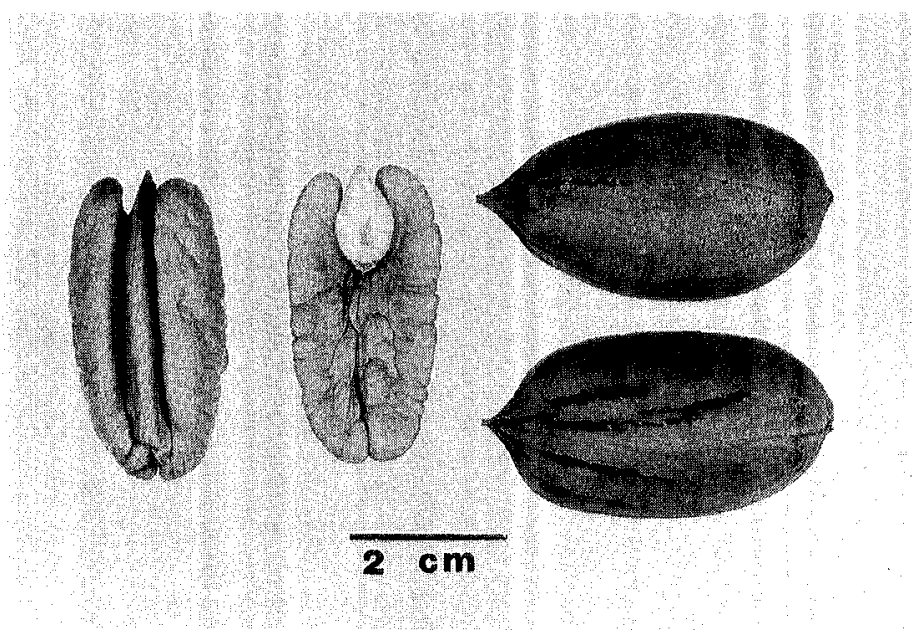

Fig. 2. Nuts and kernel halves of the 'Oconee' pecan.
Table 3. Average disease resistance rating of 'Oconee' pecan compared with control cultivars ${ }^{z, y}$

\begin{tabular}{|c|c|c|c|c|c|}
\hline \multirow[b]{2}{*}{ Cultivar } & \multicolumn{2}{|c|}{ Scab } & \multirow{2}{*}{$\begin{array}{c}\text { Downy } \\
\text { spot }\end{array}$} & \multirow{2}{*}{$\begin{array}{l}\text { Leaf } \\
\text { scorch }\end{array}$} & \multirow{2}{*}{$\begin{array}{l}\text { Vein } \\
\text { spot }\end{array}$} \\
\hline & Nut & Leaf & & & \\
\hline Oconee & 1.8 & 1.2 & 1.4 & 1.2 & 1.2 \\
\hline Desirable & 2.1 & 2.4 & 1.5 & 1.6 & 1.7 \\
\hline Cheyenne & 1.6 & 2.0 & 1.6 & 1.5 & 1.1 \\
\hline Pawnee & 1.8 & 2.8 & 2.0 & 2.0 & 1.0 \\
\hline Wichita & 3.0 & 3.0 & 2.3 & 1.9 & 1.1 \\
\hline
\end{tabular}

${ }^{2}$ Data based on evaluations at $\approx 40$ locations. 'Rating scale for all diseases: $1=$ no sign of disease; $5=$ very severe disease.

'Oconee' is protandrous and has a pollenshedding pattern similar to 'Caddo' and 'Desirable'. It likely will be a good pollinizer for most protogynous cultivars and likely will be pollenized well by 'Wichita', 'Choctaw', 'Stuart', 'Shoshoni', and many other protogynous cultivars.

'Oconee' has good scab [Cladosporium caryigenum (Ell. et Lang,) Gottwald] resistance (Table 3). In severe scab environments, this disease can be effectively managed on this clone with currently registered fungicides. 'Oconee' has fair resistance to downy spot (Mycosphaerella caryigena Demaree and Cole), and its resistance to vein spot (Gnomunia nerviseda Cole) exceeds that present in 'Desirable'.

\section{Availability}

Graftwood was supplied to nurseries and state universities and experiment stations in 1990. Scionwood or budded trees are now available from nurseries. The USDA does not have trees for distribution.

\section{Literature Cited}

Wetzstein, H.Y. and D. Sparks. 1983. The morphology of pistillate flower differentiation in pecan. J. Amer. Soc. Hort. Sci. 108:997-1003.

Worley, R.E. 1986. Variety performance at the Georgia Coastal Plains Experiment Station. Proc. Southeastern Pecan Grower's Assn. 79:39-42.

Worley, R.E. 1990. Long-term performance of pecan trees when nitrogen application is based on prescribed threshold concentrations in leaf tissue. J. Amer. Soc. Hort. Sci. 115:745-749. 